\title{
Risk perception and risk management strategies on New Zealand dairy farms according to ownership structure and geographic location
}

\author{
R. PINOCHET-CHATEAU, N.M. SHADBOLT, C.W.HOLMES and N. LOPEZ-VILLALOBOS \\ Massey University, P.O. Box 11 222, Palmerston North \\ N.M.Shadbolt@massey.ac.nz
}

\begin{abstract}
New Zealand has had many changes in the dairy industry during the last twenty years. As NZ dairy farming has particular characteristics (e.g. differing ownership structures, geographic areas) risk perception and management strategies may differ significantly between them. No studies have been undertaken regarding the differences in perception of risk and risk management strategies used by different groups of dairy farmers. A survey of $1000 \mathrm{NZ}$ dairy farmers was conducted in 2004 and further analysed to address this need. In the survey the dairy farmers were asked to assess their perception of risk sources and the importance they attached to risk management strategies. Using a 1 to 5 scale, mean scores of both risk sources and management strategies were compared (Z-test) by ownership structure and geographic location. The differences in the perception of risk between sharemilkers and owner-operators were mainly in the sources categorised as "market" and "human" "Changes in land prices" was highly important for sharemilkers. Differences of risk management strategies were noted in the "financial" and "production" categories. The main sources of risk perceived differently by farmers in the North and South Islands were in the production side of the business. Although farmers from both islands were similarly focused on controlling risk through production management strategies, those from the South Island were keener to use financial responses. In conclusion, sharemilkers were more concerned with the changes of prices of both inputs and outputs than owner-operators. Sharemilkers were more production-orientated to manage risk than farm owners, and they also were more focused on off-farm income and debt management. Differences in both the risk perception and the risk management strategies used in each island are related to differences in farm sizes and the developmental stage of the dairy sector in each island.
\end{abstract}

Keywords: risk perception, risk management strategies, sharemilkers

\section{Introduction}

New Zealand has many economic and social changes in the last 20 years. Without doubt, the most important change was the radical economic deregulation during the mid-1980s. Probably one of the most significant effects of this deregulation was on agriculture, in particular on the dairy sector. The NZ dairy industry has changed not only in its structure, through dairy co-operative mergers, which finished in 2001 with the formation of Fonterra, but also at the farm level. On farm there has been increased cow genetic merit, increased farm size with higher milksolids (MS) production per hectare and per cow, the development of new areas for dairying and new ownership structures such as equity partnerships (Holmes et al. 2002; LIC 2004). In addition, the steady increase in land prices from early in the 1980s and the decrease in real milk payout since the 1970s (LIC 2004), have imposed additional constraints on farmers. It is not surprising therefore that Pinochet-Chateau et al. (2005) reported significant differences between the way farmers perceive and manage risk now compared the results obtained by Martin (1994) in 1992. Nevertheless, risk perception and risk management are not only affected by changes in the business environment between one point in time and another; they are also affected by other factors such as the "Decision-maker's situation"(Fleisher 1990). Martin (1994) noted differences between risks perceived and risk management strategies used by different farm types (e.g. dairy, cropping, horticulture) in 1992 but her survey did not examine differences between farmers within each farm type. The objective of this paper is to compare risk perception and risk management strategies of dairy farmers of different ownership structure (owneroperators vs. sharemilkers) and geographic location (North Island vs. South Island).

\section{Methodology}

Using a holistic single-case design (Yin 2003), a sample of $1000 \mathrm{NZ}$ dairy farmers was surveyed by mail during July to mid-August 2004 (Pinochet-Chateau 2005). The Livestock Improvement Corporation (LIC) provided the sample to be surveyed, which followed the same distribution pattern as the dairy herds operating in NZ during the 2002/2003 season (LIC 2003). Therefore in the sample analysed, $83 \%$ of the farmers were from the North Island and $17 \%$ from the South Island. There was no ownership structure targeted in the sample. Of the 1000 surveys sent out, 429 surveys were returned and usable responses were obtained from 426 by September 15 th.

The 2004 Survey was based on that developed by Martin (1994), used in 1992, and it covered the following 
Table 1 Mean scores ${ }^{1}$ and ranking of the nineteen risk sources listed in the survey according to ownership structure.

\begin{tabular}{|c|c|c|c|c|c|c|c|c|}
\hline \multirow[b]{2}{*}{ Risk source } & \multicolumn{3}{|c|}{$\begin{array}{l}\text { Owners } \\
\text { Mean }\end{array}$} & \multirow[b]{2}{*}{ Rank } & \multicolumn{3}{|c|}{$\begin{array}{l}\text { Sharemilkers } \\
\text { Mean }\end{array}$} & \multirow[b]{2}{*}{ Rank } \\
\hline & $\mathrm{N}$ & score $^{1}$ & SD & & $\mathrm{N}$ & score $^{1}$ & SD & \\
\hline \multicolumn{9}{|l|}{ Market risks } \\
\hline Changes in product prices & 319 & $3.99^{a}$ & 0.83 & 1 & 85 & $4.20^{b}$ & 0.67 & 1 \\
\hline Changes in world economic and political situation & 320 & 3.78 & 0.89 & 2 & 86 & 3.76 & 0.80 & 4 \\
\hline Change in New Zealand's economic situation & 319 & 3.58 & 0.87 & 7 & 86 & 3.60 & 0.84 & 7 \\
\hline Changes in inputs costs & 320 & $3.71^{a}$ & 0.84 & 3 & 86 & $3.92^{b}$ & 0.75 & 3 \\
\hline \multicolumn{9}{|l|}{ Financial risks } \\
\hline Changes in interest rates & 320 & 3.63 & 1.08 & 5 & 86 & 3.56 & 1.05 & 8 \\
\hline Changes in land prices & 320 & $3.00^{a}$ & 1.12 & 14 & 86 & $3.43^{b}$ & 1.19 & 10 \\
\hline \multicolumn{9}{|l|}{ Production risks } \\
\hline Rainfall variability & 320 & 3.58 & 1.02 & 8 & 86 & 3.74 & 0.94 & 5 \\
\hline Other weather factors & 320 & 2.99 & 0.99 & 15 & 85 & 3.12 & 0.93 & 15 \\
\hline Diseases or pests & 320 & 3.40 & 1.06 & 10 & 86 & 3.62 & 0.90 & 6 \\
\hline Disasters & 317 & 2.61 & 1.17 & 17 & 84 & 2.57 & 1.20 & 19 \\
\hline \multicolumn{9}{|l|}{ Regulatory risks } \\
\hline Changes in government laws and policies & 320 & 3.61 & 0.93 & 6 & 86 & 3.49 & 0.88 & 9 \\
\hline Changes in local bodies laws and regulations & 321 & $3.46^{a}$ & 0.93 & 9 & 86 & $3.20^{b}$ & 0.97 & 14 \\
\hline Changes in producer board policies & 318 & 3.15 & 1.02 & 11 & 86 & 3.35 & 0.96 & 13 \\
\hline \multicolumn{9}{|l|}{ Human risks } \\
\hline Accidents or health problems & 321 & $3.66^{a}$ & 1.02 & 4 & 85 & $3.95^{b}$ & 1.08 & 2 \\
\hline Changes in family situation & 320 & $3.05^{a}$ & 1.17 & 13 & 86 & $3.42^{b}$ & 1.25 & 11 \\
\hline \multicolumn{9}{|l|}{ Miscellaneous risks } \\
\hline Theft & 319 & $2.75^{a}$ & 1.01 & 16 & 86 & $3.06^{b}$ & 1.02 & 16 \\
\hline Problems with hired labour and contractors & 320 & $3.06^{a}$ & 1.13 & 12 & 86 & $3.38^{b}$ & 1.10 & 12 \\
\hline Changes in technology and breeding & 319 & $2.52^{a}$ & 0.94 & 18 & 86 & $2.78^{b}$ & 0.95 & 17 \\
\hline Being unable to meet contracting obligations & 317 & $2.33^{a}$ & 1.02 & 19 & 86 & $2.64^{b}$ & 1.08 & 18 \\
\hline
\end{tabular}

1 Mean score from 1 to 5 ( 1 = not important, $5=$ extremely important); different letters indicate statistical difference between the mean scores of the two groups ( $Z$ test at the $5 \%$ level).

points:

- Farm ownership structure

- Overall risk perception

- Perception of risk sources: six groups of risk sources were identified (market, financial, production, regulatory, human and miscellaneous groups of risk) making up a total of nineteen sources listed.

- Risk management strategies most commonly used: four groups of risk management responses were included from the Martin (1994) survey (production, marketing, financial, overall management strategies) and a fifth group was added, strategic planning, based on a survey by Fetsch et al. 2001, making a total of twenty six strategies used to manage risk.

- Property and personal information

- Description of farmers (age, educational level, others)

- Description of farms (both physical and financial)

The relative importance attached to the different risk sources and risk management practices used by each farmer was captured using a Likert format $1-5$ scale $(1=$ less important, $5=$ very important - Likert 1961). The results show an ordinal level of measurement where numbers have an inherent order (more to less, stronger to weaker, bigger to smaller) but do not indicate the magnitude of differences between the numbers in the way that an interval or ratio level of measurement would. Mean scores were then obtained for each one of the sources and risk management strategies and comparisons were made between the mean scores of respective groups of farmers using the $\mathrm{z}$-test $(\mathrm{P}<0.05)$. The farmers were also asked to indicate if they did or did not use each risk management strategy and the percentage of farmers using each strategy was calculated. The surveys (1992 and 2004) did not attempt to assess the risk profile of each farmer, the degree to which they were risk averse, risk neutral or risk seekers, but instead just measured their perception of what created risk for their businesses and what importance they put on strategies that addressed that risk.

The analysis of the survey was divided into stages. The first, reported by Pinochet et al. (2005), compared the findings from this 2004 survey with those for dairy farmers within the 1992 survey reported by Martin (1994). The next stage, reported by this paper, was to stratify the data according to ownership structure (owneroperator, sharemilker, manager) and geographic location (North Island \& South Island).

\section{Results and discussion}

Ownership structure

The small number of survey responses from managers 
meant that this group was not considered suitable for statistical analysis. Of the nineteen risk sources listed, ten showed statistical differences in perceptions between owner-operators and sharemilkers (Table 1). For the ten risk sources where the differences in perception were significant, sharemilkers had higher mean scores than owner-operators in nine of them, sharemilkers perceived more risk in those situations than owner-operators. Only for "Changes in local bodies laws and regulations" did owner-operators perceive more risk than sharemilkers (mean scores of 3.46 vs. 3.20 respectively). Changes in prices and input costs were ranked the same for both sharemilkers and owner-operators but the mean-scores were statistically higher for sharemilkers ( 4.20 and 3.92 respectively) than for owner-operators (3.99 and 3.71 respectively). Sharemilkers tend to have higher levels of debt and their capital includes depreciating assets (plant and machinery) and dairy cattle that can vary quite significantly in value from y ear to year. Owner-operators, on average, have lower levels of debt and their capital also includes land, an appreciating asset (Shadbolt 2004). These factors provide some background to why sharemilkers perceive they are more at risk from price and cost volatility. As sharemilking has been considered to be a stepping stone in the NZ Dairy Industry in order to achieve ownership over land, it was logical to find that land prices were perceived more importantly by sharemilkers than owner-operators (3.43 vs. 3.00 ). This group perceived that their chances of owning land are threatened if land price continues its sharp trend upward. The greater risk perceived in those human risks ("accidents and health problems" and "changes in family

Table 2 Mean scores ${ }^{1}$ and ranking of the twenty six risk management strategies included in the survey according to ownership structure.

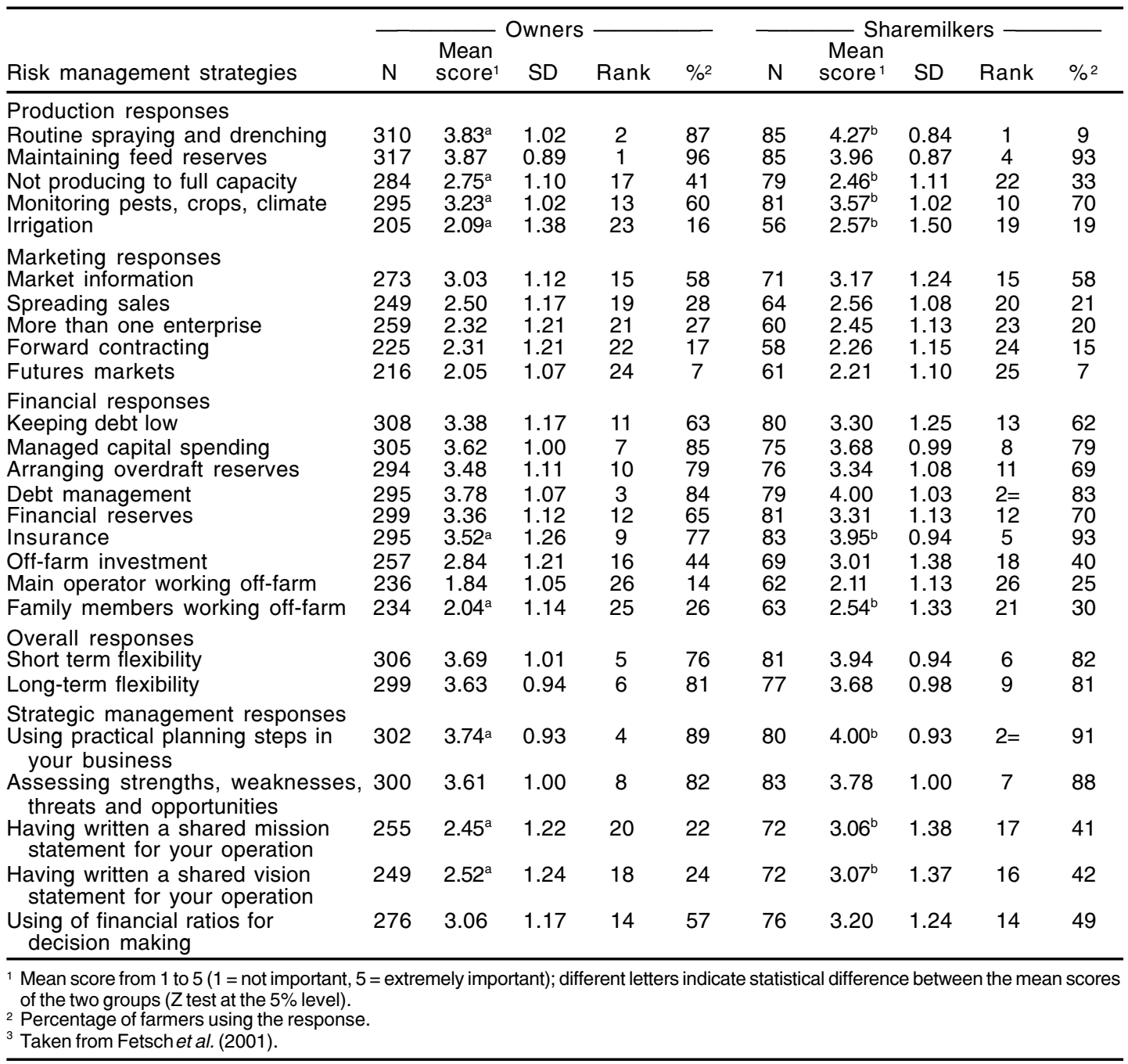


Table 3 Mean scores ${ }^{1}$ and ranking of the nineteen risk sources listed in the survey according to geographic location.

\begin{tabular}{|c|c|c|c|c|c|c|c|c|}
\hline \multirow[b]{2}{*}{ Risk source } & \multicolumn{4}{|c|}{$\begin{array}{c}\text { North Island - }- \\
345\end{array}$} & \multicolumn{4}{|c|}{ - South Island } \\
\hline & $\mathrm{N}$ & $\begin{array}{l}\text { Mean } \\
\text { score }^{1}\end{array}$ & SD & Rank & $\mathrm{N}$ & $\begin{array}{l}\text { Mean } \\
\text { score }^{1}\end{array}$ & SD & Rank \\
\hline \multicolumn{9}{|l|}{ Market risks } \\
\hline Changes in product prices & 339 & 4.02 & 0.78 & 1 & 81 & 4.07 & 0.88 & 1 \\
\hline Changes in world economic and political situation & 341 & 3.79 & 0.87 & 2 & 81 & 3.75 & 0.84 & 3 \\
\hline Change in New Zealand's economic situation & 341 & 3.57 & 0.88 & 7 & 80 & 3.65 & 0.80 & 7 \\
\hline Changes in inputs costs & 341 & 3.76 & 0.83 & 3 & 81 & 3.77 & 0.84 & 2 \\
\hline \multicolumn{9}{|l|}{ Financial risks } \\
\hline Changes in interest rates & 340 & 3.60 & 1.09 & 6 & 81 & 3.67 & 1.00 & 6 \\
\hline Changes in land prices & 341 & 3.07 & 1.17 & 13 & 81 & 3.17 & 1.05 & 13 \\
\hline \multicolumn{9}{|l|}{ Production risks } \\
\hline Rainfall variability & 341 & $3.67^{a}$ & 0.99 & 5 & 81 & $3.40^{\mathrm{b}}$ & 1.03 & 10 \\
\hline $\begin{array}{l}\text { Other weather factors } \\
\text { Diseases or pests }\end{array}$ & $\begin{array}{l}341 \\
341\end{array}$ & $\begin{array}{l}3.01 \\
3.49 \mathrm{a}\end{array}$ & $\begin{array}{l}1.00 \\
1.02\end{array}$ & $\begin{array}{c}15 \\
9\end{array}$ & $\begin{array}{l}80 \\
81\end{array}$ & $\begin{array}{l}3.10 \\
3.20^{\mathrm{b}}\end{array}$ & $\begin{array}{l}0.85 \\
1.05\end{array}$ & $\begin{array}{l}15 \\
12\end{array}$ \\
\hline Disasters & 337 & $2.55^{\mathrm{a}}$ & 1.16 & 18 & 80 & $2.95^{b}$ & 1.21 & 16 \\
\hline \multicolumn{9}{|l|}{ Regulatory risks } \\
\hline Changes in government laws and policies & 341 & 3.55 & 0.93 & 8 & 81 & 3.68 & 0.86 & 5 \\
\hline Changes in local bodies laws and regulations & 342 & 3.39 & 0.96 & 10 & 81 & 3.49 & 0.85 & 8 \\
\hline Changes in producer board policies ${ }^{1 *}$ & 339 & 3.22 & 1.03 & 11 & 81 & 3.11 & 0.99 & 14 \\
\hline \multicolumn{9}{|l|}{ Human risks } \\
\hline Accidents or health problems & 342 & 3.71 & 1.05 & 4 & 80 & 3.73 & 0.98 & 4 \\
\hline Changes in family situation & 340 & 3.12 & 1.22 & 12 & 81 & 3.23 & 1.14 & 11 \\
\hline \multicolumn{9}{|l|}{ Miscellaneous risks } \\
\hline Theft & 340 & 2.86 & 1.03 & 16 & 81 & 2.72 & 1.05 & 17 \\
\hline Problems with hired labour and contractors & 341 & $3.06^{a}$ & 1.15 & 14 & 81 & $3.48^{b}$ & 1.00 & 9 \\
\hline Changes in technology and breeding & 341 & 2.60 & 0.97 & 17 & 80 & 2.59 & 0.88 & 18 \\
\hline Being unable to meet contracting obligations & 339 & 2.41 & 1.06 & 19 & 80 & 2.45 & 1.03 & 19 \\
\hline
\end{tabular}

1 Mean score from 1 to 5 ( 1 = not important, 5 = extremely important); different letters indicate statistical difference between the mean scores of the two groups ( $Z$ test at the $5 \%$ level).

situation") reflect the high reliance of sharemilkers not only on themselves but on their family members as well. On this point it is of interest that sharemilkers also attached a higher mean score to problems with hired labour and contractors. While sharemilkers might be expected to do most of the job themselves, human resource management is equally important for sharemilkers and owner-operators.

Sharemilkers had equal or higher mean scores than owner-operators in 16 of the 26 risk management strategies identified (Table 2). This does not mean they used them more than farm owners, but that they recognize the importance of using them to manage risk. The assessment of the use of management strategies to control risk showed that sharemilkers are more focused on most of the production strategies than owner-operators. They put more emphasis on reducing physical performance variation through practices like spraying and drenching ( 4.27 vs. 3.83 respectively), monitoring pest, crops and climate ( 3.57 vs. 3.23 respectively) and using irrigation ( 2.57 vs. 2.09 respectively). As most of these practices have associated costs, this explains in part why they perceived the changes in product prices and input costs as being so important. Of note was the sharemilker reluctance to accept 'not producing at full capacity' as an important risk management strategy; only $33 \%$ of them use it against $41 \%$ of owner-operators. It should also be taken into account that tensions created by the contractual arrangements of sharemilking could also influence the relative importance and ranking placed on a number of these risk management strategies by sharemilkers in this survey. The second highest ranked strategy for sharemilkers was debt management but their mean-score for this was not significantly different from the owneroperators. Sharemilker financial strategies that did differ significantly included insurance and off-farm work by family members. Activities off-farm are an increasingly important way to ensure business viability and to reduce risk world wide (Moredu 2000). In this sense it is a common expectation that some of the sharemilkers' family members work off-farm in order to stabilize income. Control of the threat of accidents and health problems is attempted through the greater use of personal insurance. The differences found between the two groups in strategic management are a reflection of the role of sharemilking as a step-by-step process to land ownership; plans for the development of the business become highly important if it is to succeed. This may also indicate that long-term goals set by sharemilkers motivate them to be very clear about their next steps in order to succeed. 


\section{Geographic location}

The perception of risk between Islands was different for four of the nineteen risk sources listed, and three of them were production sources of risk (Table 3). "Disasters" was the only production source of risk that was more important for farmers from the South Island than those from the North Island ( 2.95 vs. 2.55 respectively); the latter being more concerned about rainfall variability and diseases and pests, two risk sources that have a very direct impact on physical performance (3.67 vs. 3.40 and 3.49 vs. 3.20 respectively). Finally, farmers from the South Island were more concerned about "Problems with hired labour and contractors" than those from the North Island (3.48 vs. 3.06 respectively) reflecting the effect of scale of the operations, the increased reliance on hired staff and the lack of high skilled labour for
South Island farmers. In this survey farm and herd size from the South Island were statistically significantly larger than the North Island.

Statistical differences between the mean scores of the two groups of farmers were found in seven of the twenty six risk management strategies listed in the five groups (Table 4). Differences were found in the use of production and financial risk management strategies.

Confirming the finding that farmers from the North Island perceive more risk in diseases and pests than those from the South Island, the former group of farmers consider routine spray and drenching as the top strategy to manage risk, whereas this strategy was ranked 9 th by farmers in the South Island. Another major difference in the importance and use of specific risk management strategies was the use of irrigation. In the South Island

Table 4 Mean scores ${ }^{1}$ and ranking of the twenty six risk management strategies included in the survey according to geographic location.

\begin{tabular}{|c|c|c|c|c|c|c|c|c|c|c|}
\hline \multirow[b]{2}{*}{ Risk management strategies } & \multicolumn{5}{|c|}{ North Island } & \multicolumn{5}{|c|}{ _ South Island } \\
\hline & $\mathrm{N}$ & $\begin{array}{l}\text { Mean } \\
\text { score }^{1}\end{array}$ & SD & Rank & $\% 2$ & $\mathrm{~N}$ & $\begin{array}{l}\text { Mean } \\
\text { score }^{1}\end{array}$ & SD & Rank & $\%^{2}$ \\
\hline \multicolumn{11}{|l|}{ Production responses } \\
\hline Routine spraying and drenching & 334 & $4.00^{a}$ & 0.96 & 1 & 90 & 76 & $3.59^{b}$ & 1.16 & 9 & 81 \\
\hline Maintaining feed reserves & 340 & 3.93 & 0.87 & 2 & 96 & 77 & 3.77 & 0.93 & 5 & 91 \\
\hline Not producing to full capacity & 303 & 2.64 & 1.10 & 17 & 37 & 74 & 2.80 & 1.13 & 20 & 49 \\
\hline Monitoring pests, crops, climate & 316 & 3.32 & 1.06 & 13 & 61 & 75 & 3.19 & 1.05 & 14 & 70 \\
\hline Irrigation & 213 & $1.92 \mathrm{a}$ & 1.15 & 26 & 9 & 60 & $3.33^{b}$ & 1.84 & 11 & 52 \\
\hline \multicolumn{11}{|l|}{ Marketing responses } \\
\hline Market information & 286 & 3.05 & 1.14 & 15 & 57 & 69 & 3.10 & 1.21 & 16 & 61 \\
\hline Spreading sales & 265 & 2.54 & 1.14 & 19 & 28 & 62 & 2.37 & 1.24 & 22 & 23 \\
\hline More than one enterprise & 269 & 2.35 & 1.22 & 21 & 26 & 64 & 2.38 & 1.12 & 21 & 31 \\
\hline Forward contracting & 236 & 2.28 & 1.19 & 22 & 15 & 60 & 2.35 & 1.23 & 23 & 24 \\
\hline Futures markets & 233 & 2.13 & 1.06 & 24 & 7 & 56 & 1.95 & 1.17 & 24 & 11 \\
\hline \multicolumn{11}{|l|}{ Financial responses } \\
\hline Keeping debt low & 324 & 3.40 & 1.18 & 10 & 64 & 76 & 3.21 & 1.21 & 13 & 57 \\
\hline $\begin{array}{l}\text { Managed capital spending } \\
\text { Arranging overdraft reserves }\end{array}$ & $\begin{array}{l}317 \\
310\end{array}$ & $\begin{array}{l}3.67 \\
3.38\end{array}$ & $\begin{array}{l}0.97 \\
1.13\end{array}$ & $\begin{array}{c}6 \\
12\end{array}$ & $\begin{array}{l}84 \\
74\end{array}$ & $\begin{array}{l}76 \\
72\end{array}$ & $\begin{array}{l}3.53 \\
3.67^{b}\end{array}$ & $\begin{array}{l}1.05 \\
1.03\end{array}$ & $\begin{array}{c}10 \\
7\end{array}$ & $\begin{array}{l}86 \\
78\end{array}$ \\
\hline Debt management & 313 & 3.79 & 1.10 & 3 & 83 & 73 & 3.92 & 0.97 & 1 & 82 \\
\hline Financial reserves & 318 & 3.40 & 1.11 & 11 & 69 & 74 & 3.26 & 1.15 & 12 & 54 \\
\hline Insurance & 316 & 3.58 & 1.23 & 9 & 80 & 76 & 3.84 & 1.10 & 3 & 86 \\
\hline Off-farm investment & 272 & 2.90 & 1.25 & 16 & 43 & 67 & 2.82 & 1.25 & 19 & 47 \\
\hline Main operator working off-farm & 251 & $1.98^{a}$ & 1.13 & 25 & 18 & 60 & $1.57^{b}$ & 0.74 & 26 & 9 \\
\hline Family members working off-farm & 248 & $2.23^{a}$ & 1.25 & 23 & 28 & 62 & $1.81^{b}$ & 0.99 & 25 & 25 \\
\hline \multicolumn{11}{|l|}{ Overall responses } \\
\hline Short term flexibility & 327 & 3.78 & 0.97 & 5 & 79 & 74 & 3.61 & 1.07 & 8 & 75 \\
\hline Long-term flexibility & 316 & 3.64 & 0.99 & 7 & 80 & 73 & 3.67 & 0.76 & 6 & 85 \\
\hline \multicolumn{11}{|l|}{ Strategic management responses } \\
\hline $\begin{array}{l}\text { Using practical planning steps in } \\
\text { your business }\end{array}$ & 321 & 3.78 & 0.95 & 4 & 89 & 74 & 3.85 & 0.86 & 2 & 93 \\
\hline $\begin{array}{l}\text { Assessing strengths, weaknesses, } \\
\text { threats and opportunities }\end{array}$ & 320 & 3.62 & 1.02 & 8 & 82 & 77 & 3.79 & 0.89 & 4 & 88 \\
\hline $\begin{array}{l}\text { Having written a shared mission } \\
\text { statement for your operation }\end{array}$ & 277 & $2.53^{\mathrm{a}}$ & 1.31 & 20 & 25 & 65 & $2.91^{b}$ & 1.16 & 18 & 33 \\
\hline $\begin{array}{l}\text { Having written a shared vision } \\
\text { statement for your operation }\end{array}$ & 271 & $2.57^{\mathrm{a}}$ & 1.32 & 18 & 27 & 64 & $3.02^{b}$ & 1.15 & 17 & 35 \\
\hline $\begin{array}{l}\text { Using of financial ratios for } \\
\text { decision making }\end{array}$ & 295 & 3.07 & 1.20 & 14 & 55 & 71 & 3.18 & 1.14 & 15 & 59 \\
\hline
\end{tabular}


$52 \%$ of the farmers use it (it was ranked 11 th), compared with only $9 \%$ of the farmers from the North Island (it was ranked 26th). Although a similar proportion of farmers from both Islands arrange overdraft reserves as a way of managing risk, this strategy was more important for farmers from the South Island (ranked 12th vs. 7th in the North and South Islands, respectively). This may reflect the greater seasonality of South Island production or the greater levels of overall debt due to the rapid expansion of dairy farming businesses in the South Island, whereas in the North Island the business might be considered more stable. It was also evident from the present survey, that off-farm work, either by the farmer $\mathrm{him} /$ herself or some of his/her family members, was more important for farmers from the North Island, although in both islands it achieved a low ranking. This outcome could be related to size of farm and herd, or availability of alternative sources of income. Within the strategic planning responses, for every strategy listed, a greater proportion of farmers from the South Island used them than those from the North Island. Significant differences, however, were found only for both the written mission and vision of the business ( 2.91 vs. 2.53 and 3.02 vs. 2.57 respectively), which could be linked to the developmental stage of the dairy industry in the South Island.

\section{Conclusions}

Clear differences were found in the risk perceived and the risk management strategies according to ownership structure (owner-operators vs. sharemilkers) and geographic location (North Island vs. South Island). Sharemilkers were more concerned with the changes of prices of both inputs and outputs than owner-operators. Sharemilkers were more production-orientated to manage risk than farm owners, and they also were more focused on off-farm income and debt management. Differences in both the risk perception and the risk management strategies used in each island are related to differences in farm sizes and the developmental stage of the dairy sector in each island

Perception of risk can be a precursor to adoption of risk management strategies. The differences noted between farmer groups in their perception of risk and the importance they place on risk management strategies can be very valuable to those developing and improving extension programs for dairy farmers. Risk management strategies that address noted areas of concern are likely to be more readily accepted than those that address possible, but lower ranked, areas of concern.

\section{REFERENCES}

Fetsch, R. J.; Bastian, C.; Kaan, D. A.; Koontz, S. R. 2001. A two-state comparison of farmers' and ranchers' risk management education needs. Journal of the American Society of Farm Managers and Rural Appraisers 66: 81-92.

Fleisher, B. 1990. Agricultural risk management. Lynne Rienner Publishers. Boulder, Colorado, USA.

Holmes, C. W.; Brookes,I. M.; Garrick, D. J.; Mackenzie, D. D. S.; Parkinson, T. J.; Wilson, G. F. 2002. Milk production from pasture. Principles and practices. Massey University. Palmerston North.

LIC 2003. New Zealand Dairy Statistics 2002-2003. Livestock Improvement Corporation, Hamilton.

LIC 2004. New Zealand Dairy Statistics 2003-2004. Livestock Improvement Corporation, Hamilton.

Likert, R. 1961, New Patterns of Management, McGrawHill, USA.

Martin, S. K. 1994. Risk perceptions and management responses to risk in pastoral farming in New Zealand. Proceedings of the New Zealand Society of Animal Production 54: 363-368.

Moreddu, C. 2000. Approaches to income risk management in OECD countries: overview of farm household strategies and government intervention, $\mathrm{pp}$. 17-61. In: Income Risk Management in Agriculture. OECD.

Pinochet-Chateau, R.; Shadbolt N.M.; Holmes C.; LopezVillalobos N. 2005. Differences in risk perception and risk management strategies used by New Zealand dairy farmers. Proceedings of the Annual World Food and Agribusiness Forum, Symposium and Case Conference 15: www.ifama.org/conferences/2005 Conference.

Pinochet-Chateau, R. 2005. Risk in New Zealand dairy farming: Perception and management. Master of Applied Science Thesis. Massey University, Palmerston North.

Shadbolt, N. 2004. Financial measures of business success. Proceedings of the Anmual Conference of the New Zealand Large Herds Association 35: 64-70. 